\title{
Recent Investigations into Ancient Maya Domestic and Ritual Activities at Pook's Hill, Belize
}

\author{
Christophe G.B. Helmke \\ UCL Institute of Archaeology
}

\section{Keywords}

Funerary practices, household archaeology, Maya, sweatbath

\section{Introduction}

A fifth season of excavations was conducted between June and September 2005 at the ancient Maya site of Pook's Hill, Belize (Helmke 2006a). The excavations were conducted as part of the Belize Valley Archaeological Reconnaissance Project (BVAR) under the direction of Jaime Awe (Belize Institute of Archaeology). The site is located in the Roaring Creek Valley of central Belize, in the Cayo District, approximately $14 \mathrm{~km}$ southwest of the country's capital, Belmopan (Fig. 1). The site is situated amidst the karstic foothills to the granitic Maya Mountains at an approximate elevation of $78 \mathrm{~m}$ above mean sea level.

\section{Site Description}

The principal complex of Pook's Hill is a residential site with masonry structures of various functions facing onto and delineating a quadrilateral plaza. Such residential groups are known as plazuelas and follow Maya architectural practices, in being quadrangular and aligned to major cardinal directions (Ashmore 1981, 49-54). The plazuela has been termed "Pook's Hill Group 1" (or PKH1) and now that it has been extensively cleared it is known to consist of the remains of nine masonry building platforms (cf.
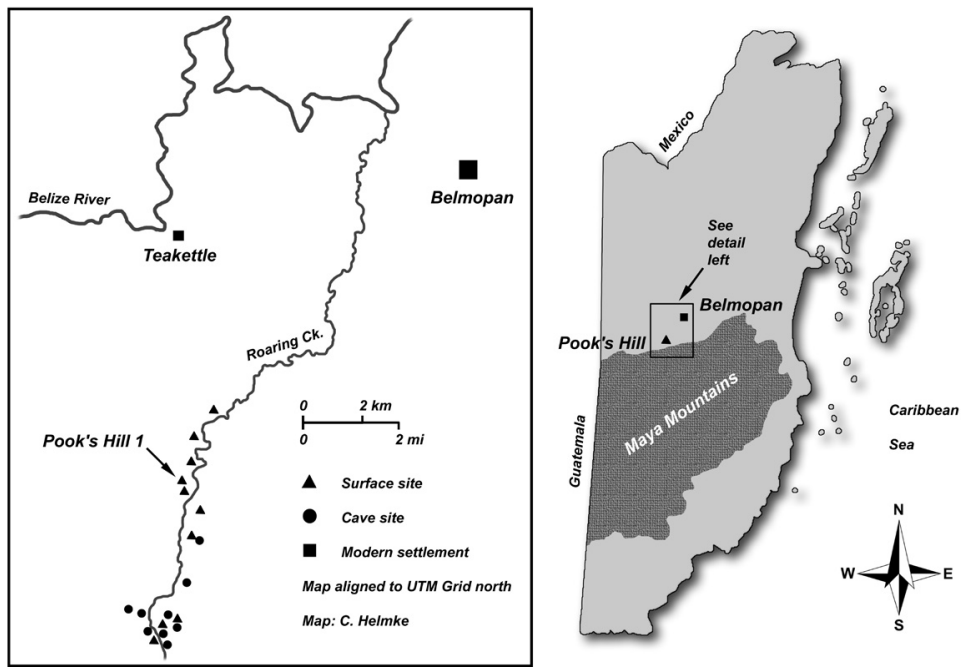

Figure 1. Maps of Belize and the Roaring Creek Valley showing the location of the Pook's Hill plazuela. 
Helmke 2003: 119; 2006a: 42-43) (Fig. 2). The largest building (Structure 1A), measures $16.5 \mathrm{~m}$ long (east-west) by c. $5.4 \mathrm{~m}$ wide (north-south) and is over $2.5 \mathrm{~m}$ high (above the ancient plastered plaza). The group as a whole encompasses an area of approximately $1106 \mathrm{~m}^{2}$ of which the plaza occupies just over $430 \mathrm{~m}^{2}$.
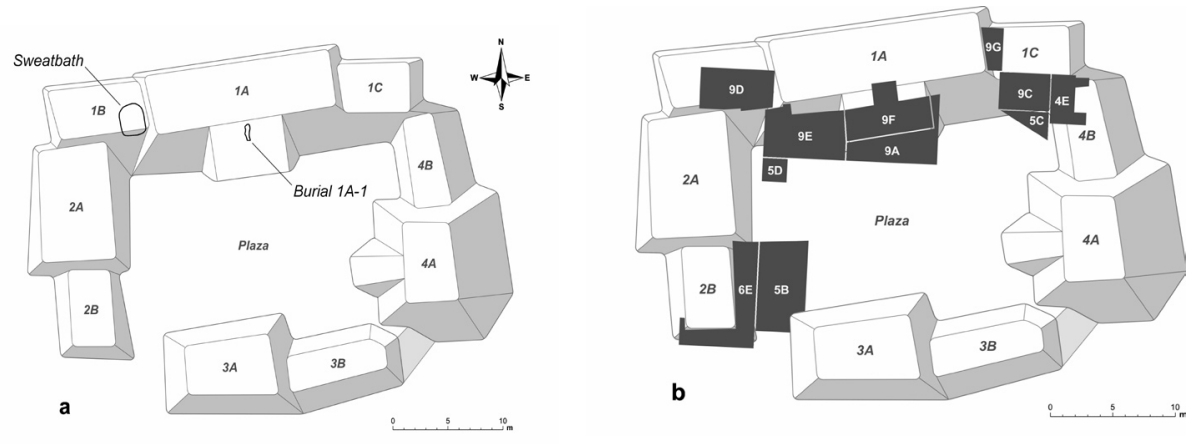

Figure 2. Plan of the Pook's Hill plazuela. a) The plazuela with the collapsed structures rendered as conventionalised mounds. The sweatbath and Burial 1A-1 discussed in the text are indicated as outlines; b) the plazuela with all the 2005 season excavation sub-operations marked off by shaded areas. Plan aligned to true north. Plan and survey by Christophe Helmke (1999-2005).

\section{Objectives}

The objectives of the 2005 season were threefold: 1) to continue documentation of ancient Maya domestic and ritual activities at an intermediate-sized household group in the Roaring Creek Valley; 2) to fully excavate and ascertain the function of a presumed sweatbathing building; and 3) to complete architectural restoration works of five of the site's buildings that were scheduled for consolidation (as part of tourism development efforts) (Helmke 2006a: 39). The two most important finds made during the course of the 2005 season of investigations are the focus of this article, namely a structure that has been positively identified as a sweatbath (Structure 1B) and an interment associated with the largest building at the site (Structure 1A).

\section{Results}

\section{Sweatbath}

In 2001, excavations at Pook's Hill partly exposed the frontal facade of Structure 1B. The architectural features discovered in association with the exterior of that building were strongly reminiscent and compared favourably in terms of type and dimensions to roughly coeval sweatbathing structures at the important sites of Piedras Negras and Tikal in Guatemala (Satterthwaite 1952; Jones 1996: 75-77; Helmke 2006a: 53-54; 2006b: 13, Fig. 6). In order to test the presumed sweatbathing function of that building in 2005, we completely cleared the interior of the once vaulted room of Structure 1B (Fig. 3). Based on the many features consistent with sweatbaths uncovered it can now be conclusively stated that the vaulted room of Structure 1B functioned primarily as a sweatbath (see Helmke 2006a: 53-68). Though most of the vault had collapsed in 
antiquity, we found that the sweatbath comprised a well-preserved, ovoid room (measuring $2.25 \mathrm{~m}$ wide by $2.85 \mathrm{~m}$ long). Based on well-preserved portions, it is clear that the room would have had a domed corbel vault (approximately $2.35 \mathrm{~m}$ in height; Helmke 2006a, 61-62, 64-65, Figs. 9, 13). All features of the sweatbath have heat promotion and retention as the basis of their design. The smallness of the room $\left(5.3 \mathrm{~m}^{2}\right.$ and $\mathrm{c}$. $9.6 \mathrm{~m}^{3}$ ) would have amplified heat and is entirely in keeping with other Lowland sweatbaths (which range between $2.7 \mathrm{~m}^{2}$ and $21.3 \mathrm{~m}^{2}$ ) (Helmke 2006a: 66, table 4). Similarly, the low doorway into the room $(98 \mathrm{~cm}$ high) was designed to retain heat within, while the two high masonry benches that dominate the inside would have raised bathers to the warm air gathered in the upper reaches of the room. In the rear of the room we also exposed the 'hearth' and 'firebox' of the sweatbath, where heated stones were sprinkled with water to produce steam. The rapid cooling of stones, brought about by contact with water, induced pervasive cracking and spalling of the masonry framing the hearth. Water was also used by sweatbathers to wash and rinse as is suggested by the bench

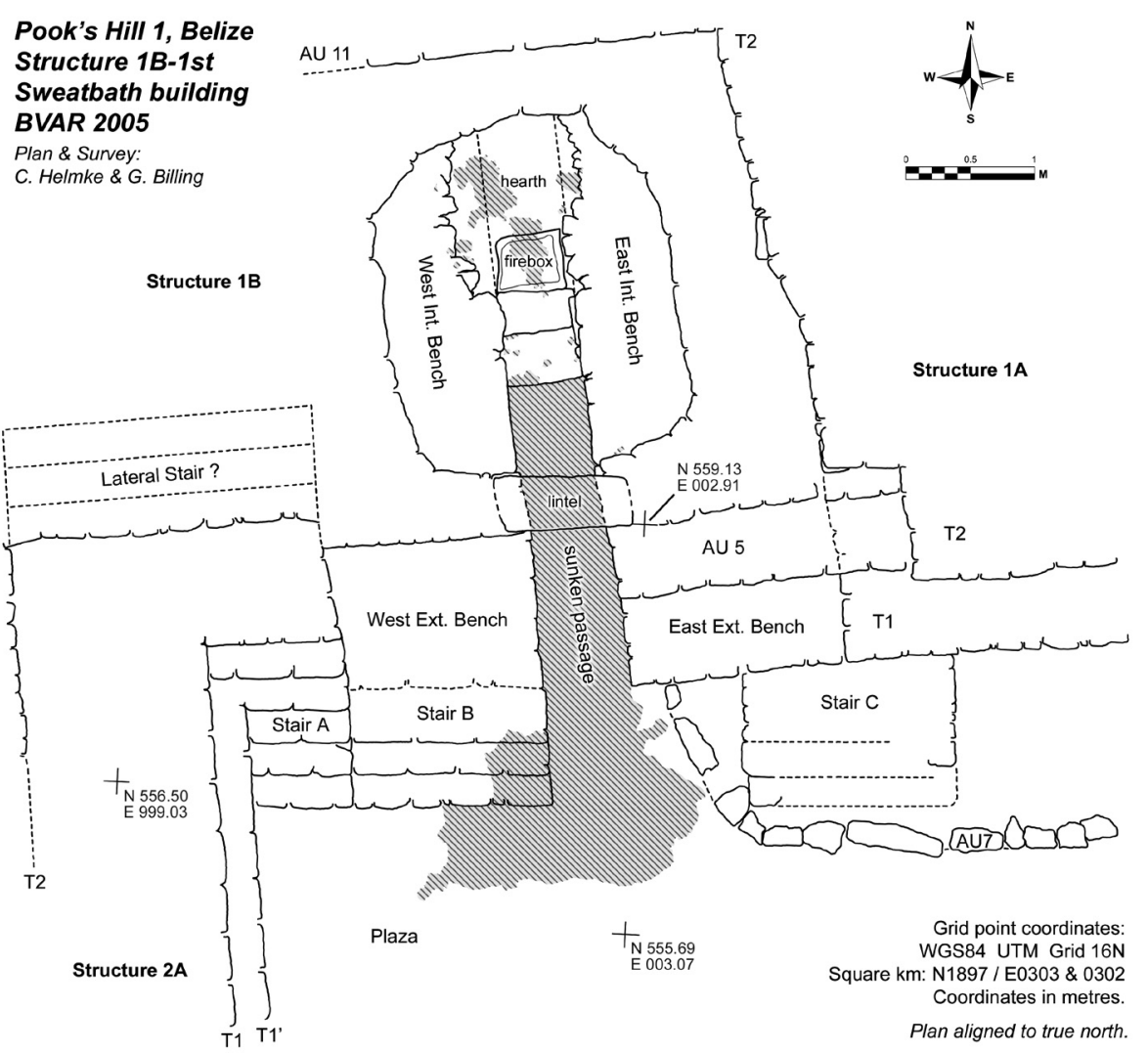

Figure 3. Plan of the terminal phase architecture of the sweatbath of Structure 1B and parts of the adjoining Structures $1 \mathrm{~A}$ and 2A. The extensive diagonally-hatched area represents the artefactual deposit that was deposited during the terminal phase of the site's occupation. Note how the deposit filled the sunken passage and obstructed the entrance to the circular sweatbathing room, thereby terminating its primary function. 


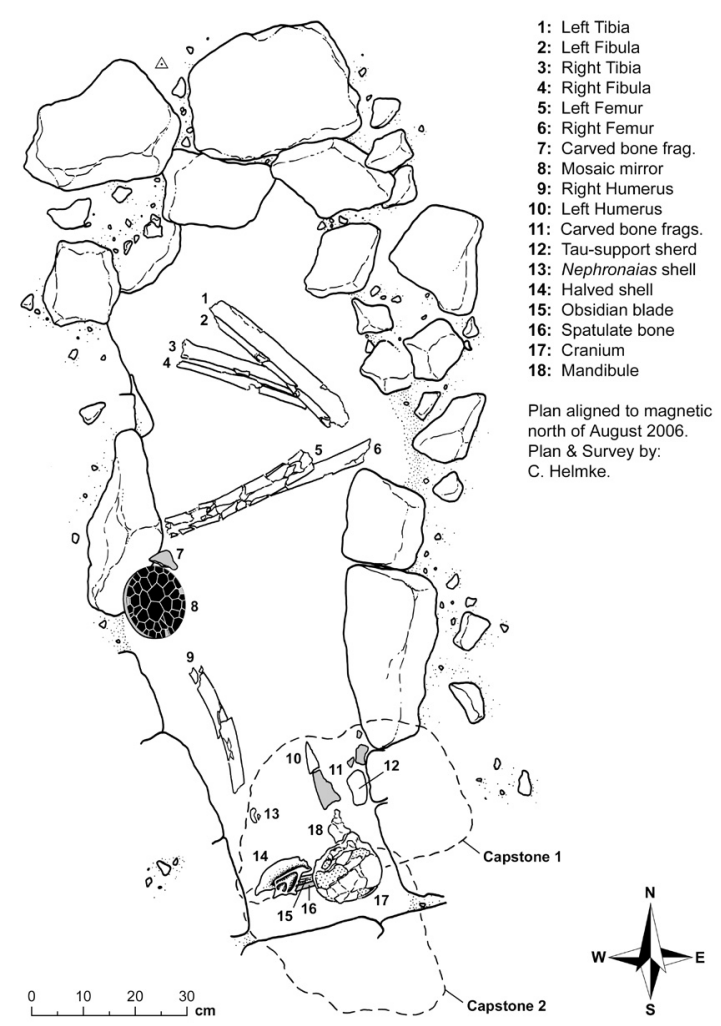

Figure 4. Plan of Burial 1A-1. Note the halved shell inkwell (no. 14) behind the cranium, the fragmented carved bone plaque (shaded in light grey) (nos. 7 and 11), and the pyrite mosaic mirror (no. 8) in relation to the poorly-preserved skeleton. The two limestone capstones that sheltered the cranial area are marked by dashed outlines.

and floor surfaces that are noticeably graded towards the entrance to promote drainage. The exterior features of the sweatbath also include a so-called 'sunken passage' which would have drained runoff from the sweatbath, southward onto the plastered plaza. The two high exterior benches that frame the 'sunken passage' in turn would have been places where bathers could disrobe prior to bathing and rinse-off thereafter (Helmke 2006a: 59, 61).

Structure 1B stands apart from all others at Pook's Hill not only in terms of its primary function but also since it is one of the latest buildings constructed at the site (Helmke 2006a: 67-68, 81-82). As a late addition, dated to the Terminal Classic (c. AD 830-950), it nonetheless witnessed considerable usage based on re-plastering of interior bench surfaces as well as the wear-polish documented along the verges of the interior benches and its floor. The primary function of the sweatbath was eventually terminated late in 


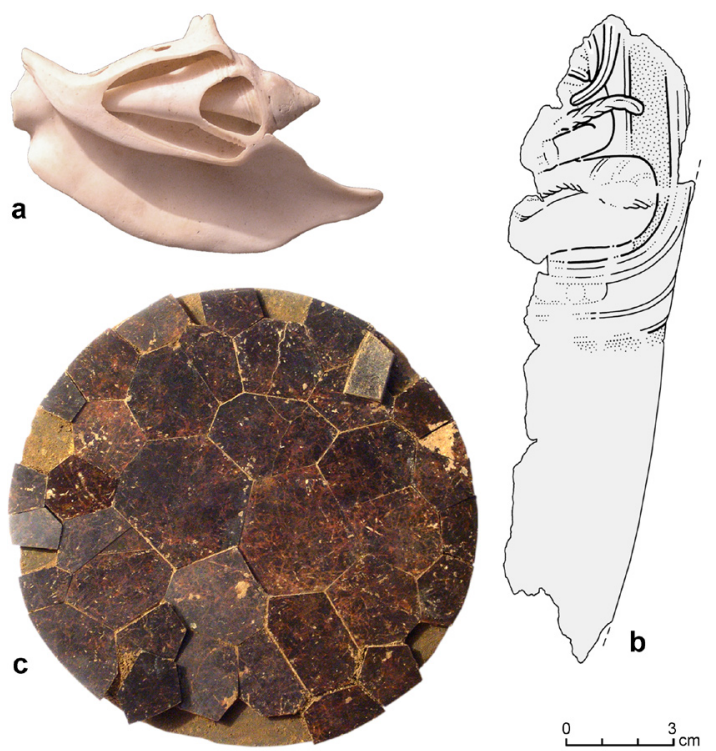

Figure 5. Artefacts of Burial 1A-1. a) The halved conch shell pendant and possible inkwell; b) the carved bone plaque with the circular iconographic cartouche with all fragments refitted; and c) the complete iron pyrite and slate mirror as found. All artefacts are rendered to scale. Photographs and drawing by Christophe Helmke.

the site's history by an extensive artefactual deposit (Fig. 3). The deposit had been cast into the vaulted room (prior to its collapse) and filled the sunken passage thereby partly obstructing entry into the room. Though still the focus of ongoing analyses, comparable deposits have been documented at several other sites, including Aguateca and Tikal in Guatemala (Harrison 1999, 193-198; Inomata et al. 2001, 292, 296-297).

\section{Burial 1A-1}

Ritual activity was signalled by Burial 1A-1, the sole 'special deposit' encountered in 2005. The interment was discovered as part of trenching excavations aligned to the 'primary axis' (Loten and Pendergast 1984: 3) of Structure 1A, which were designed to document construction sequences and test for the incidence of votive dedicatory deposits. The trench ( $2 \mathrm{~m}$ east-west by $4.3 \mathrm{~m}$ north-south) penetrated into the core of the terminal outset Stair 1 (Str. 1A-1 ${ }^{\text {st }}$ ) and revealed the presence of an earlier engulfed Stair 2. At present, it remains unknown if Stair 2 represents a 'construction stair' (see Loten and Pendergast 1984: 6) to the terminal phase architectural refurbishments (Str. $1 \mathrm{~A}-1^{\text {st }}$ ) or the stair to the penultimate phase construction (Str. 1A-2 ${ }^{\text {nd }}$ ) (Helmke 2006a: 72-73). It was in the core of Stair 2 that we found Burial 1A-1. The grave was built directly atop unmodified bedrock as a cist with two large marl capstones spanning the cranial area (Fig. 4). The skeleton was in a prone position, oriented north-south, with head to the south, as was customary at Pook's Hill and the greater Belize Valley from Middle Formative times (600 BC onwards) (see Helmke 2003, 122). The skeletal re- 
mains of the interment were poorly preserved on account of the effect of bone against limestone bedrock but the interment was notable for its artefactual inclusions. The burial contained, in addition to several items of personal adornment, a halved conch shell that may have served as a pendant and portable inkwell (Figs. 4.14 and 5a) (see Coe and Kerr 1997: 101, 105, 150-151; Reents-Budet 1994: 36-38, 42-43), a fragmentary carved bone plaque and a complete circular mosaic mirror (Helmke 2006a: 75-80; Stanchly 2006: 107). The carved bone plaque represents an iconographic panel showing an anthropomorphic figure, holding what may be a feather-tipped blood-letter, seated cross-legged, within a lunar ancestor cartouche (Figs. 4.7, 4.11 and 5b). The absence of ceramic containers in the interment complicates matters of dating, though based on the dates ascribed to adjoining architecture and the style of the carved bone plaque, the burial can be provisionally dated to the Late Classic (c. AD 700-830) (Helmke 2006a: 69-70, 80-81). The mosaic mirror is one of the most complete of its kind and is composed of a solid, smoothed slate backing, to which 45 iron pyrite tesserae were adhered (Figs. 4.8 and $5 \mathrm{c}$ ). The position within the burial and the perforations of the slate backing indicate that the mirror was worn as an item regalia on a belt assemblage at the small of the back in keeping with burial evidence from other sites and iconographic depictions thereof (Figs. 4.14 and 5d) (Miller and Taube 1993: 114-115; Taube 1992: 172-177).
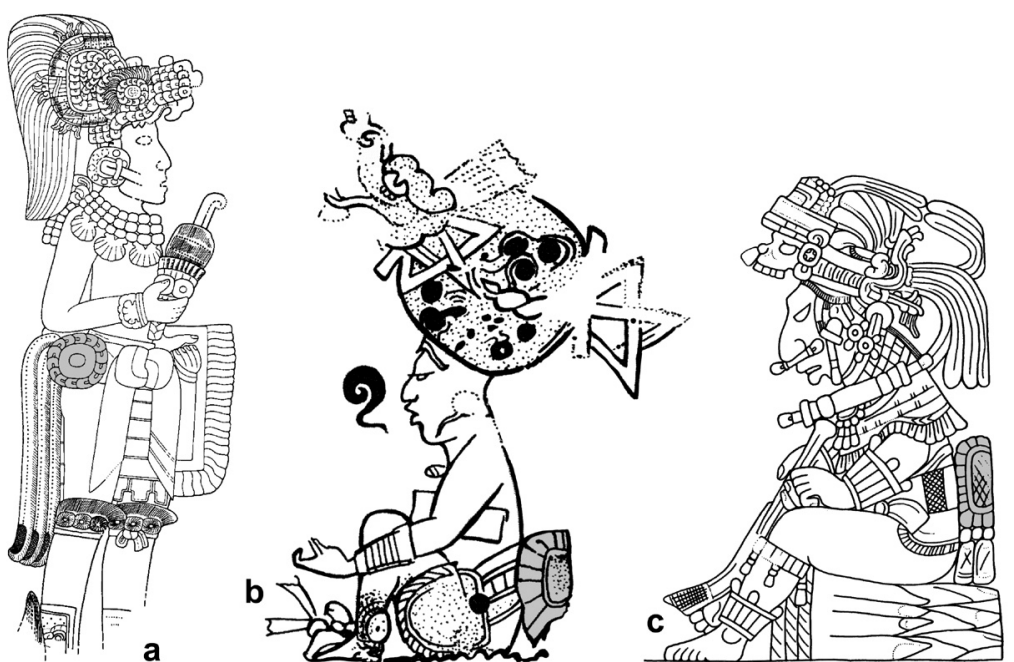

Figure 6. Examples of mirrors worn at the small of the back in Early and Late Classic Maya iconography. Mirrors are accentuated by grey shading. a) Left side of Stela 31, Tikal (AD 445); b) detail of a codex-style ceramic dish, Mirador Basin (c. AD 700); and c) detail of Lintel 17, Yaxchilan (c. AD 752-768). Note that two of the figures are rendered wearing Teotihuacan-inspired headdresses and regalia (a and b). Drawings adapted from originals by William Coe, Simon Martin and Ian Graham, respectively. 


\section{Discussion and Conclusions}

The finds made at Pook's Hill in 2005 provide a varied picture of local social processes during the 'collapse' period that characterises the Terminal Classic period (c. AD 830950). In this regard, the sweatbath and the burial are particularly illustrative. What sets the sweatbath of Pook's Hill apart is its circular plan, which contrasts to the quadrilateral examples seen at the important centres of Piedras Negras, Palenque, Tikal and Copan (Cheek 2003: 134-135; Jones 1996: 75-77; Robertson 1985: 79-80; Satterthwaite 1952). The circular shape is, however, seen in the earliest domed examples (Hammond and Bauer 2001) as well as in modern cases in the Mexican and Guatemalan Highlands (see Satterthwaite 1952). The pattern that emerges is that of two competing sweatbathing traditions, one regally-sanctioned and associated with monumental rectangular sweatbaths (i.e. c. $11-24 \mathrm{~m}^{2}$ ), versus a vernacular tradition of great longevity and geographic breadth, often associated with smaller domed sweatbaths (i.e. 3-8 $\mathrm{m}^{2}$ ) (Helmke 2006a, 66-67). As such, the Classic period examples of domed sweatbaths (Pook's Hill for example), may be seen as direct precursors the ones that have been typical in Mesoamerica since the period of Spanish contact (see Arreola 1920; Cresson 1938: 90-96; Satterthwaite 1952: 7-10; Hammond and Bauer 2001: 684; Helmke 2006a: 67).

In turn, one of the most interesting aspects of Burial 1A-1 is the placement of the mosaic mirror as worn by the deceased. The practice of wearing mirrors at the small of the back is one of many traditions introduced to the Maya area in the late Early Classic (AD 375 onwards) under the influence of Mexico's great and distant metropolis Teotihuacan (Taube 1992: 172-174; Miller and Taube 1993: 114; Nielsen 2006: 5, 6). With the waning of Teotihuacan's power and its eventual abandonment in the seventh century, many Teotihuacan-inspired practices fell into disuse. A great revivalism in Teotihuacan iconography and regalia has, however, been noted at major centres such as Tikal, Piedras Negras and Copan during the early part of the eight century (Martin and Grube 2000: 45, 142, 207-208; Stone 1989; Stuart 2000: 490, 495-498; 2005: 387-393). As Burial 1A-1 has been dated to the Late Classic it is contemporaneous to the revivalistic practices currently seen elsewhere in the Lowlands and thus can be deemed to be a local adherence to these trends.

Though the results presented here are provisional, it is hoped that with continued analyses these finds will contribute to our understanding of the particular social processes involved in the transitional Terminal Classic period in this area of the Maya world.

\section{Acknowledgements}

My thanks are due to the Belizean Institute of Archaeology, its Director and its members for their continuing support and granting permission to conduct work at Pook's Hill since 1999. Jaime Awe as director of the BVAR project is thanked for the opportunity to investigate Pook's Hill as well as providing invaluable logistical and financial assistance during the course of the season. My gratitude is also due to Ray and Vicki Snaddon for allowing excavations on their property, providing ideal lodgings, as well as supplying unwavering financial and logistical support. The contributions and hard work of all those who have participated in the 2005 season investigations are 
warmly thanked, particularly the support of Andrew Bevan, Mario Carbajal, Carlos Chuc, Benjamin Cruz, Manuel Cunil, Cameron Griffith, Rafael Guerra, Amelia McCullough, Christopher Morehart, Julie Nehammer Knub, Gilberto Puc Jr., José Puc, Nazario Puc, Myka Schwanke, Becky Scopa, Martin Sneddon, Norbert Stanchly, Gabe Wrobel and all BVAR field school students of 2005. Finally, I would like to thank my family for continuous support and encouragement during every one my field seasons. All omissions and interpretative shortcomings remain those of the author.

\section{References}

Arreola, J. M. 1920. El temazcal o baño de vapor. Ethnos 1(2), 28-33.

Ashmore, W. 1981. Some Issues of Method and Theory in Lowland Maya Settlement Archaeology, in Ashmore, W. (ed.) Lowland Maya Settlement Patterns. Albuquerque: University of New Mexico Press, 37-69.

Cheek, C. D. 2003. Maya Community Buildings: Two Late Classic popol nahs at Copan, Honduras. Ancient Mesoamerica 14, 131-138.

Coe, M. D. and J. Kerr. 1997. The Art of the Maya Scribe. London and New York: Thames \& Hudson.

Cresson, F. M. 1938. Maya and Mexican Sweat Houses. American Anthropologist 40(1), 88-104.

Hammond, N. and Bauer, J. R. 2001. A Preclassic Maya Sweatbath at Cuello, Belize. Antiquity 75(290), 683-684.

Harrison, Peter D. 1999. The Lords of Tikal: Rulers of an Ancient Maya City. London and New York: Thames \& Hudson.

Helmke, C. G.B. 2006a. A Report of the 2005 Season of Archaeological Investigations at Pook's Hill, Cayo District, Belize, in Helmke, C. G.B. and Awe, J. J. (eds.) The Belize Valley Archaeological Reconnaissance Project: A Report of the 2005 Field Season. Belmopan: Belize Institute of Archaeology, 39-92.

Helmke, C. G.B. 2006b. A Summary of the 19992002 Seasons of Archaeological Investigations at Pook's Hill, Cayo District, Belize. Research Reports in Belizean Archaeology 3, 173-191.
Helmke, C. G.B. 2003. The 2002 Season Investigations at Pook's Hill, Belize. Papers from the Institute of Archaeology 14, 119-128.

Inomata, T., Triadan, D., Ponciano, E., Richard, T., and Beaubien, H. F. 2001. In the Palace of the Fallen King: The Royal Residential Complex at Aguateca. Journal of Field Archaeology 28(3/4), 287-306.

Jones, C. 1996. Excavations in the East Plaza of Tikal. Philadelphia: Tikal Report 16, University Museum Monograph 92, University of Pennsylvania.

Loten, H. S. and Pendergast, D. M. 1984. A Lexicon for Maya Architecture. Toronto: Archaeology Monograph 8, Royal Ontario Museum.

Martin, S. and Grube, N. 2000. Chronicle of the Maya Kings and Queens: Deciphering the Dynasties of the Ancient Maya. London and New York: Thames \& Hudson.

Miller, M. and Taube, K. 1993. An Illustrated Dictionary of the Gods and Symbols of Ancient Mexico and the Maya. London and New York: Thames \& Hudson.

Nielsen, Jesper. 2006. The Queen's Mirrors: Interpreting the Iconography of Two Teotihuacan Style Mirrors from the Early Classic Margarita Tomb at Copan. PARI Journal 4(4), 1-8.

Reents-Budet, D. 1994. Painting the Maya Universe: Royal Ceramics of the Classic Period. Durham: Duke University Press.

Robertson, M. G. 1985. The Sculpture of Palenque, Volume III: The Late Buildings of the Palace. Princeton: Princeton University Press. 
Satterthwaite, L. Jr. 1952. Piedras Negras Architecture, Part V, Sweathouses. Philadelphia: University Museum, University of Pennsylvania.

Stanchly, N. 2006. A Preliminary Analysis of the Pook's Hill Vertebrate Faunal Assemblage, in Helmke, C. G.B. and Awe, J. J. (eds.) The Belize Valley Archaeological Reconnaissance Project: A Report of the 2005 Field Season. Belmopan: Belize Institute of Archaeology, 93115 .

Stone, A. 1989. Disconnection, Foreign Insignia and Political Expansion: Teotihuacan and the Warrior Stelae of Piedras Negras, in Diehl, R. A. and Berlo, J. C. Mesoamerica after the Decline of Teotihuacan AD 700-900. Washington DC: Dumbarton Oaks Research Library and Collection, 153-172.

Stuart, D. 2005. A Foreign Past: The History and Representation of History on a Royal Ancestral Shrine at Copan, in Andrews, E. W. and Fash, W. L. (eds.) Copán: The History of an Ancient Maya Kingdom. Santa Fe: School of American Research Press, 373-394.

2000. 'The Arrival of Strangers': Teotihuacan and Tollan in Classic Maya History, in Carrasco, D. and Jones, L. (eds.) Mesoamerica's Classic Heritage: Teotihuacán to the Aztecs. Boulder: University of Colorado Press, 465-513.

Taube, K. 1992. The Iconography of Mirrors at Teotihuacan, in Berlo, J. C. (ed.) Art Ideology, and the City of Teotihuacan. Washington DC: Dumbarton Oaks Research Library and Collection, 169204. 